УДК 94(479.24+479.25) «2020»:355.1:930

ХАРУК А.I.

https://orcid.org/0000-0003-3459-1657

https://doi.org/10.33577/2313-5603.35.2021.281-290

\title{
ВИСВІТЛЕННЯ ВІРМЕНО-АЗЕРБАЙДЖАНСЬКОГО ЗБРОЙНОГО КОНФЛІКТУ 2020 Р. У ПОЛЬСЬКИХ СПЕЦАЛІЗОВАНИХ ВИДАННЯХ
}

У статті розглянуті питання висвітлення в польських військових часописах подій, відомих як Друга карабаська війна (27 вересня - 10 листопада 2020 р.). Відзначено, що цей воєнний конфлікт знайшов відображення у низці статей, опублікованих майже в режимі реального часу. Часом це призводило до публікації неперевіреної й недостовірної інформації. Сюжети проаналізованих нами матеріалів відзначаються певною однобічністю, а саме - помітним перекосом у бік аналізу застосування безпілотних літальних апаратів та проблем протидії ним. На другий план відійшов аналіз застосування традиційних засобів збройної боротьби (танків, артилерії тощо). Можна стверджувати, що досліджені нами публікації польської фахової преси можуть бути використані при вивченні історії Другої карабаської війни, але за умови ретельної перевірки викладених у них фактів шляхом зіставлення з іншими джерелами.

Ключові слова: Азербайджан, Вірменія, Нагірний Карабах, Друга карабаська війна, безпілотні літальні апарати.

Постановка проблеми та ї̈ актуальність. Однією з важливих проблем історіографії воєнної історії $\epsilon$ аналіз та узагальнення матеріалів висвітлення сучасних збройних конфліктів. Результати такого аналізу слугуватимуть відправною точкою для історичних досліджень. Значний інтерес становлять публікації польської спеціалізованої військової періодики. Польські автори намагаються оперативно відстежувати сучасні збройні конфлікти, прикладом чого можуть бути їхні численні публікації, де розглядається російська агресія проти України. Систематизація та вивчення публікацій польських фахівців, присвячених збройним конфліктам останніх десятиліть, сприятиме розширенню джерельної бази вітчизняної військово-історичної думки.

Аналіз попередніх досліджень $i$ публікацій. Українська історіографія накопичила певний досвід аналізу та узагальнення матеріалів польської спеціалізованої преси стосовно російської агресії проти України (Харук, 2015; Харук, 2016). Поряд 3 тим

Харук Андрій Іванович, доктор історичних наук, професор, завідувач кафедри гуманітарних дисциплін Національної академії сухопутних військ імені гетьмана Петра Сагайдачного, м. Львів.

(C) Харук A.I., 2021 
питання висвітлення та осмислення польськими фахівцями інших збройних конфліктів останніх десятиліть, зокрема вірмено-азербайджанського, залишаються поза увагою вітчизняних дослідників.

Мета та завдання дослідження. У нашій статті маємо за мету проаналізувати особливості висвітлення у польських військових виданнях передумов, ходу та наслідків вірмено-азербайджанського збройного конфлікту 2020 р., застосування у ньому різноманітних видів зброї, а також висновки, які роблять 3 цього конфлікту польські дослідники.

Виклад основного матеріалу дослідження. 27 вересня 2020 р. спалахнув черговий вірмено-азербайджанський конфлікт, відомий також як Друга карабаська війна. Не будемо вдаватися до глибшого аналізу причин цього конфлікту та ходу бойових дій, зрештою, це не $\epsilon$ метою нашої розвідки. Зазначимо лише, що Друга карабаська війна була зумовлена нерозв'язаністю карабаського питання, а саме - існуванням на території Азербайджану непідконтрольної його владі самопроголошеної «Нагірно-Карабаської Республіки» (НКР). Військова операція Азербайджану тривала 44 дні і завершилась 10 листопада 2020 р. встановленням контролю законної влади над значною частиною самопроголошеної республіки та всією протяжністю азербайджано-іранського кордону.

Польські військові часописи практично в режимі реального часу відслідковували хід Другої карабаської війни. Вже в жовтневому числі часопису Wojsko i Technika була опублікована перша частина розлогого матеріалу Марціна Гавенди (Gawęda, $2020 a$ ). Стаття вийшла, ще коли точились бої, тож це наклало певний відбиток на зміст і спосіб подачі матеріалу. Автор часто вдається до припущень, оперує непідтвердженою інформацією. Зокрема, це стосується припущень про участь турецьких офіцерів у плануванні операції та турецьких операторів - в управлінні азербайджанськими безпілотними літальними апаратами (БПЛА) (Gawęda, 2020a:30). М. Гавенда також займає виразно означену провірменську позицію, використовуючи для позначення Нагірного Карабаху термін «Арцах» і стверджуючи, що війну 2020 р. спровокувала азербайджанська сторона.

На думку М. Гавенди, Друга карабаська війна відбувалася у кількох вимірах, причому до звичних тактичного й оперативного він додає ще і пропагандистський. В останньому боротьба велась за села, тоді як у тактичному вимірі головними цілями були 
укріплені висоти і хребти, а в оперативному - ключові дороги, які пов'язували Вірменію з Нагірним Карабахом. Для обох сторін головним чинником проєкції сили, як у наступі, так і в обороні (контрнаступі) стала артилерія (ствольна та реактивна), яка здійснювала масовані обстріли не лише позицій противника, але й цілей в глибині його розташування - комунікацій і районів зосередження військ. Цілком новим чинником стало масоване застосування БПЛА азербайджанською стороною. Сили оборони невизнаної НКР виявились неготовими до відбиття масованих атак $з$ повітря - вони не тільки не мали ефективної системи ППО, але й не вміли застосовувати пасивні засоби оборони (наприклад, маскування) (Gawęda, 2020a:31). Автор також аналізує озброєння вірменських та азербайджанських військ, дуже стисло - їхню організацію (переважно частин армії НКР) та хід бойових дій на початковому етапі - 327 вересня до 5 жовтня 2020 р.

Друга частина статті М. Гавенди - це хроніка бойових дій в період з 6 до 31 жовтня 2020 р. (Gawęda, 2020b). Особливу увагу автор приділив боям за міста Гадрут і Фізулі, а також наступу азербайджанської армії на Лачин 3 метою перерізати головну комунікаційну лінію, яка пов' язувала Нагірний Карабах з Вірменією (Gawęda, 2020b:41-43). Автор підкреслює технологічну перевагу азербайджанської армії - завдяки застосуванню БПЛА вона отримувала достатньо повну інформацію про розташування i переміщення військ противника. Сили ж оборони НКР внаслідок «децимації» своєї артилерії в другій половині жовтня змушені були дедалі більше зміщувати акцент у бік піхоти. Остання, діючи $з$ засідок невеликими групами, посиленими ПТРК, намагалась сповільнити наступ азербайджанських частин. Противагою такій тактиці стало застосування азербайджанцями груп спеціального призначення, які проникали за лінію ворожої оборони, ведучи розвідувально-диверсійні дії (Gawęda, 2020b:40). М. Гавенда детально аналізує застосування вірменською стороною балістичних ракет та заходи збройних сил Азербайджану зі знищення пускових установок цих ракет (Gawęda, 2020b:44-45). Аналізуючи війну в повітрі, автор статті наголошує, що використання традиційної пілотованої авіації (штурмовиків Су-25, гелікоптерів Мi-24) обома сторонами було епізодичним. Головну ж роль відігравали БПЛА, причому, на думку М. Гавенди, роль вірменських безпілотників у конфлікті недооцінена, а успіхи азербайджанських - занадто 
розрекламовані. Неспростовним, однак, залишається факт «виключення» 3 бою вірменської системи ППО: БПЛА та інші вогневі засоби Азербайджану успішно знищували не тільки ЗРК малої дальності «Оса-АК/АКМ», але й елементи зенітно-ракетних систем С-300ПС (Gawęda, 2020b:45-46).

Заключну частину статті М. Гавенди опубліковано в грудневому числі Wojsko i Technika (Gawęda, 2020c). Автор аналізує бої за м. Шуша, які він називає останньою великою сутичкою війни. Він підкреслює суттєву роль, яку відіграла в цих боях азербайджанська легка піхота. На думку М. Гавенди, саме в боях за Шушу сили оборони «НКР» вичерпали свої останні резерви (Gawęda, 2020c:52-53). Також висвітлені останні епізоди протистояння в повітрі: збиття 8 листопада вірменським ЗРК «Тор-М2МК» БПЛА «Байрактар» ТВ2, знищення наступного дня цього ЗРК азербайджанськими безпілотниками та помилкове збиття азербайджанськими засобами ППО російського гелікоптера Мi-24П (зі складу військового контингенту РФ у Вірменіï) (Gawęda, 2020c:53-54). Найбільше уваги в статті приділено аналізові причин поразки «НКР» та іï наслідків. При цьому наслідки розглянуті однобічно - лише для Вірменії, під кутом критики опозицією нераціонального військового будівництва (насамперед закупівель озброєння, яке виявилось малопридатним у війні) (Gawęda, 2020c:54-56). М. Гавенда вказує на чотири основні причини перемоги Азербайджану: перевага в повітрі і масове застосування БПЛА; технічна перевага, насамперед - широке застосування безпілотних літальних апаратів; кількісна перевага (легенда про участь у боях за Карабах трьох армій - азербайджанської, турецької та сирійських бойовиків); всебічна політична і військова підтримка Туреччини. Зупиняючись на останньому чиннику, автор відзначає, що саме він відрізняв Другу карабаську війну від попередніх конфліктів у цьому регіоні (у квітні 2016 р. і липні 2020 р.). Ще однією причиною поразки вірменської сторони, на думку М. Гавенди, стала ключова помилка уряду Вірменії - відмова від відправки до Нагірного Карабаху регулярних частин армії цієї країни. Щоправда, вже в наступному реченні дослідник вказує на обгрунтованість такого рішення 3 огляду на міжнародну ізоляцію Вірменії та відсутність підтримки з боку Російської Федерації (Gawęda, 2020c:57-58). 
Два матеріали Марціна Стрембського, присвячені повністю або частково Другій карабаській війні, опублікував в останніх числах за 2020 р. часопис Lotnictwo. Перший - це стаття-монографія про турецький безпілотний літальний апарат «Байрактар» ТВ2 (Strembski, 2020a). Відповідно до формату статті основну увагу автор приділив історії створення цього БПЛА, його конструкції та озброєнні, коротко охарактеризовано службу «Байрактара» TB2 у військово-повітряних силах Азербайджану. Дослідник зазначає, що до початку Другої карабаської війни ні Азербайджан, ні Туреччина офіційно не повідомляли про продаж цих БПЛА до Азербайджану. М. Стрембські підкреслює, що застосування БПЛА над сильнопересіченою місцевістю дозволило азербайджанській армії нівелювати тактичну перевагу вірменської сторони, позиції якої знаходились на панівних висотах. Азербайджанські «Байрактари» не тільки знищували опорні пункти, танки, бронемашини, вантажівки, артилерійські позиції за допомогою керованих боєприпасів, але й коригували вогонь ствольної та реактивної артилерії. Завдяки цьому суттєво зросла точність ураження цілей некерованими боєприпасами та скоротився час реакції, потрібний для відкриття вогню по виявлених цілях (Strembski, 2020a:27).

Друга стаття повністю присвячена авіаційним аспектам війни у Нагірному Карабасі (Strembski, 2020b). Автор дає кількісну та якісну характеристку військової авіації й ППО сторін конфлікту. Підкреслено, що сили оборони «НКР» не мали військової авіації взагалі, а ВПС Вірменії суттєво поступались азербайджанським, навіть не зважаючи на отримання чотирьох сучасних багатоцільових винищувачів Су-30СМ. М. Стрембовський стверджує, що упродовж усього конфлікту на території Азербайджану знаходився турецький контингент чисельністю близько 600 чол., який мав шість винищувачів F-16C, вісім гелікоптерів та кільканадцять розвідувальних БПЛА. Турецькі офіцери виконували функції радників у штабах та інструкторів операторів ударних БПЛА. Крім того, турецькі БПЛА та літаки далекого радіолокаційного виявлення Е-7Т здійснювали польоти над територією Туреччини уздовж кордону з Вірменією. Зібрана ними розвідувальна авіація передавалась Азербайджану. У свою чергу, на території Вірменії знаходився російський авіаційний контингент (ескадрилья винищувачів МіГ-29СМТ та ескадрилья гелікоптерів Мi-24П і Mi-8MT). (Strembski, 2020b:16-18). 
Основна частина статті М. Стрембського - це хроніка бойових дій зі скрупульозним розбором епізодів бойового застосування військової авіації та засобів протиповітряної оборони. При цьому дослідникові довелось дуже критично підходити до інформації, яка подавалась сторонами конфлікту. Скажімо, вже в перший день бойових дій (27 вересня 2020 р.) вірменська сторона заявила про знищення чотирьох азербайджанських гелікоптерів і 16 БПЛА, але азербайджанці визнали лише ушкодження одного гелікоптера (Strembski, 2020b:19). Досить детально М. Стрембський аналізує епізод знищення вірменського штурмовика Су-25К 29 вересня. Він обгрунтовано піддає сумніву заяву міністерства оборони Вірменії про те, що штурмовик став жертвою турецького $\mathrm{F}-16 \mathrm{C}$, схиляючись до версії, що Су-25К збив азербайджанський винищувач МiГ-29 (Strembski, 2020b:21). Приблизно у такому ж ключі - із зіставленням інформації з вірменських та азербайджанських джерел - проаналізовано інші епізоди, коли та чи інша сторона заявляли про знищення ворожих літальних апаратів. Серед висновків, сформульованих дослідником, на першому місці стоїть необхідність застосування пасивної протиповітряної оборони (використання багатоспектральних засобів маскування, швидка зміна позицій після виконання вогневого завдання тощо). Також важливим $є$ прикриття військ зенітними комплексами малої дальності, здатними уражати повільні повітряні цілі (БПЛА) (Strembski, 2020b:30).

Друга Карабаська війна стала справжньою «війною безпілотників». БПЛА застосовувались тут в небачених раніше на пострадянському просторі масштабах і суттєво вплинули на результат бойових дій. Цей аспект не залишився поза увагою польських дослідників. Зокрема, йому присвячений матеріал, опублікований у грудневому числі часопису Lotnictwo Aviation International (Gawenda, 2020d). Стаття характеризується двома особливостями. По-перше, у ній досліджено використання БПЛА не лише у бойових діях вересня-листопада 2020 р., але й під час попередніх загострень вірмено-азербайджанського конфлікту - у квітні 2016 р. і липні 2020 р. (Gawenda, 2020d:62-63). По-друге, в цій статті достатньо докладно розглнуто наявний склад БПЛА Вірменії та їхнє бойове застосування - тоді як більшість авторів інших публікацій, присвячених вірмено-азербайджанському конфлікту, зосереджують увагу на азербайджанських безпілотниках 
(Gawenda, 2020d:64-65). Поряд із традиційними БПЛА, розглянуто й використання одноразових ударних безпілотників (баражуючих боєприпасів). У висновках автор підкреслює, що було б спрощенням стверджувати, що війну в Нагірному Карабасі виграли безпілотники. Ключем до перемоги стало синергетичне застосування БПЛА та інших видів озброєння. Винятково успішне використання безпілотників (насамперед, «Байрактар» ТВ2 і «Хароп») пояснювалось також ефективним здобуттям й аналізом розвідувальних даних, плануванням і веденням операцій, а також доброю підготовкою операторів (Gawenda, 2020d:69).

Наприкінці 2020 - на початку 2021 рр. 3’явились публікації, присвячені участі в Другій карабаській війні окремих родів зброї танків та артилерії. Зазначено, що обидві сторони використовували в бою майже однотипні танки - Т-72. В той же час, армія Азербайджану мала принаймні частину танків сучасніших модифікацій; крім того, на південній ділянці фронту вона використовувала і танки Т-90С. Азербайджанські війська також обмежено застосовували застарілі танки Т-55, але виключно в ролі самохідної артилерії. Наведено дані щодо втрат танків обома сторонами конфлікту. Назагал стаття не містить глибшого аналізу тактики застосування танків у війні (Gawenda, 2020e).

Стаття, присвячена артилерії, містить аналіз якісного і кількісного складу ствольної та реактивної артилерії обох сторін. Автор вказує на наявність як застарілих систем радянських взірців, так $\mathrm{i}$ нових або модернізованих, підкреслюючи, що Азербайджан пішов у цій галузі значно далі, ніж Вірменія. Автор стверджує, що азербайджанська армія використовувала свої найновіші артсистеми на південній ділянці фронту, де здійснювався прорив вірменських позицій. Особливо акцентуєься на використанні новітніх зразків зброї, наприклад автоматизованих 120-мм мінометних систем «Кардом»/«Спір» ізраїльського виробництва.

Широкий асортимент боєприпасів, у тому числі й високоточних, дозволяв азербайджанцям підбирати оптимальні засоби ураження для кожного конкретного випадку, що підвищувало ефективність вогню артилерії. Артилерія ж сил оборони «НКР» дуже швидко була нейтралізована (фактично винищена) противником. За 44 дні боїв вона втратила майже 300 артсистем (Gawenda, 2021). 
Висновки. Чергове загострення військового протистояння в Нагірному Карабасі, яке перетворилось на повномасштабну війну, викликало значний інтерес серед польських фахівців. Відобразилось це у низці статей, опублікованих у спеціалізо-ваних військових часописах. Аналізуючи ці публікації, можна зазначити декілька характерних особливостей. Головна 3 них це публікація матеріалів майже в режимі реального часу. Це пояснюється прагненням якомога оперативніше інформувати читачів, але є й негативні наслідки - розміщення неперевіреної $\mathrm{i}$ недостовірної інформації. Тому до використання вказаних статей у військово-історичних дослідженнях слід підходити обережно, перевіряючи наведені в них факти за іншими джерелами.

Сюжети проаналізованих матеріалів характеризуються певною однобічністю, а саме - помітним перекосом у бік аналізу застосування безпілотних літальних апаратів та проблем протидії їм. Не в останню чергу це зумовлено пропагандою азербайджанської сторони, яка подавала бойові дії в Нагірному Карабасі як «війну дронів». Однак не підлягає сумніву те, що БПЛА дійсно відіграли величезну роль у Другій карабаській війні. Польські дослідники приділили цьому належну увагу. Натомість на другий план відійшов аналіз застосування «конвенційних» засобів збройної боротьби (танків, артилерії тощо). Таким чином, можна стверджувати, що досліджені нами публікації польської фахової преси можуть бути використані при вивченні історії Другої карабаської війни, але за умови ретельної перевірки викладених у них фактів шляхом зіставленням з іншими джерелами.

\section{Використані посилання}

Харук А.І. 2015. Деякі аспекти висвітлення у зарубіжній періодиці участі української авіації в антитерористичній операції на Сході України (за публікаціями 2014 р.). Військово-науковий вісник, вип. 24, С. 206 - 218.

Харук А.І. 2016. Висвітлення у спеціалізованій періодиці участі української авіації в Антитерористичній операції: спроба історіографічного аналізу. Військово-науковий вісник, вип. 25, С. $255-265$.

Gawęda M. 2020a. Nowa odsłona wojny w Górskim Karabachu. Cz. 1. Wojsko $i$ Technika, №10, S. 30-36.

Gawęda M. 2020b. Nowa odsłona wojny w Górskim Karabachu. Cz. 2. Wojsko i Technika, №11, S. 40-46. 
Gawęda M. 2020d. Systemy BSP w koflikcie azerbejdżańsko-armeńskim. Lotnictwo Aviation International, №12, S. 62-69.

Gawęda M. 2020e. Czotgi w II Wojnie Karabaskiej URL: https://www.defence24.pl/ czolgi-w-ii-wojnie-karabaskiej [Дата звернення 10 лютого 2021 p.].

Gawęda M. 2021. Artyleria w II Wojnie Karabaskiej URL: https://www.defence24.pl/ artyleria-w-ii-wojnie-karabaskiej [Дата звернення 10 лютого 2021 p.].

Strembski M. 2020a. Bairaktar TB2. Dziryt sułtana - turecki dron bojowy. Lotnictwo, №11, S. 16-29.

Strembski M. 2020b. Lotnicze aspekty walk w Górskim Karabachu. Lotnictwo, №12, S. 16-31.

\section{References}

Gawęda M. 2020a. Nowa odsłona wojny w Górskim Karabachu. Cz. 1. Wojsko i Technika, №10, s. 30-36 (pol).

Gawęda M. 2020b. Nowa odsłona wojny w Górskim Karabachu. Cz. 2. Wojsko $i$ Technika, №11, s. 40-46 (pol).

Gawęda M. 2020c. Nowa odsłona wojny w Górskim Karabachu. Cz. 3. Wojsko $i$ Technika, №12, s. 52-58 (pol).

Gawęda M. 2020d. Systemy BSP w koflikcie azerbejdżańsko-armeńskim. Lotnictwo Aviation International, №12, s. $62-69$ (pol).

Gawęda M. 2020e. Czołgi w II Wojnie Karabaskiej URL: https://www.defence24.pl/ czolgi-w-ii-wojnie-karabaskiej [Accessed 10 February 2021] (pol).

Gawęda M. 2021. Artyleria w II Wojnie Karabaskiej URL: https://www.defence24.pl/ artyleria-w-ii-wojnie-karabaskiej [Accessed 10 February 2021] (pol).

Kharuk A.I. 2015. Some aspects of coverage in foreign periodicals participation of Ukrainian aviation in Antiterrorist operation (on publications 2014). MilitaryScientific Bulletin, issue 24, pp. 206-218 (ukr).

Kharuk A.I. 2016. Coverage in specialized periodicals participation of Ukrainian aviation in Antiterrorist operation: an attempt to historiographical analysis. MilitaryScientific Bulletin, issue 25, pp. 255-265 (ukr).

Strembski M. 2020a. Bairaktar TB2. Dziryt sułtana - turecki dron bojowy. Lotnictwo, № 11, S. 16-29 (pol).

Strembski M. 2020b. Lotnicze aspekty walk w Górskim Karabachu. Lotnictwo, № 12, S. 16-31 (pol). 


\section{Kharuk A. \\ COVERAGE OF THE ARMENIAN-AZERBAIJANI MILITARY CONFLICT OF 2020 IN POLISH SPECIALIZED PUBLICATIONS}

Escalation of the military confrontation in Nagorno-Karabakh in the fall of 2020 turned into a full-scale war. It has aroused considerable interest among foreign experts, including Polish ones, who are closely monitoring the armed conflicts in the post-Soviet space. This is reflected in a number of articles published in specialized military journals. Analyzing these publications, we can note several characteristics. The main one is the publication of materials almost in real time. This is due to the desire to inform readers as quickly as possible, but also has negative consequences - the placement of unverified and unreliable information. Therefore, the use of these articles in military history research should be approached with caution, checking the facts presented in them from other sources.

The plots of the materials analyzed by us are marked by a certain one-sidedness, namely, a noticeable skew towards the analysis of the use of unmanned aerial vehicles and the problems of counteracting them. Last but not least, this is due to the propaganda measures of the Azerbaijani side, which presented the fighting in Nagorno-Karabakh as a «drone war». However, there is no doubt that UAVs really played a huge role in the Second Karabakh War. Polish researchers have paid due attention to this. Instead, the analysis of the use of «conventional» means of armed struggle (tanks, artillery, etc.) took a back seat. Thus, it can be argued that the publications of the Polish professional press studied by us can be used in the study of the history of the Second Karabakh War, but subject to careful verification of the facts set forth in them by comparison with other sources.

Keywords: Azerbaijan, Armenia, Nagorno-Karabakh, Second Karabakh War, unmanned aerial vehicles. 